\title{
漢樂蒼耳, 研究
}

醫學士 估土丁

(満洲醫科大學藥物學呚室 〔久保四敎授】)

(昭和十・年三月二十三日受付)

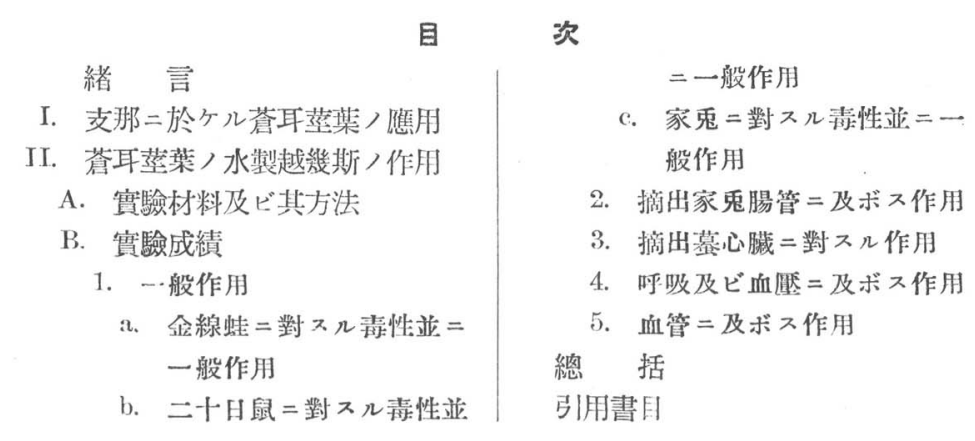

緒言

荅耳ハ料科二屬スル 1 年生草本ニシテ學名みXanthium strumarium, L. をなもみト 稱シ，北米，南歐及ビ亞細亞ノ原野二廣ク自生セリ。

本植物, 根, 蕉葉, 子賽等八印度及ビ支那二於テハ古クヨリ民間藥トシテ㗨藥ノ川二

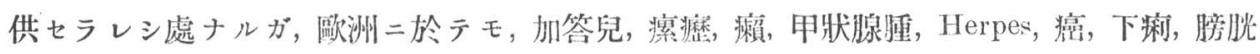

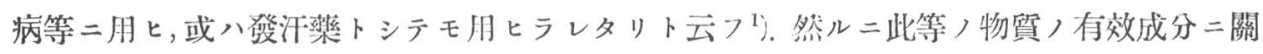
シテハ僅カ二 1881 年 Zander ${ }^{2}$ ) ガ本植物, 實中ヨリ無晶形配煻體ナルXanthostrumarin 並

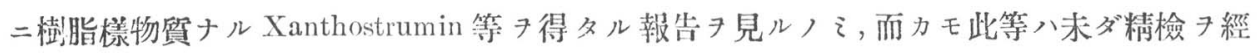
ザル處ニシテ, 其)如何ナル物質ナルヤ明ラカナラザルノミナラズ, 其葲理ニ關シラハ未 多何人二依テモ檢索タ試ミラレシコトアルタ聞カザルナリ. 余八奉天附近ノ荒野二自生セ

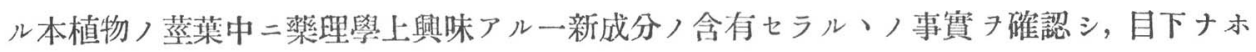
夫ノ精檢中ナルガ, 爱二取敢へズ之二關スル卑近ナル支那醫書) 記述习探采, 併セテ本植物 蒸葉ノ水浸液二就テ行へル賽噞ノ結果キ報告スベシ.

\section{I. 支那二於与儿蒼耳莖葉ノ應用}

蒼耳八支那二於テ八甚名古クヨリ利ラレタル植物ノ一ニシテ, 既二詩經 ${ }^{3}$ ) 爾雅 ${ }^{4}$ 等, 如キ古書二其記載が見ラレ, 從テ其名稳ノ如キモ 


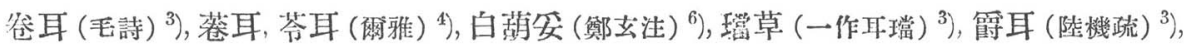

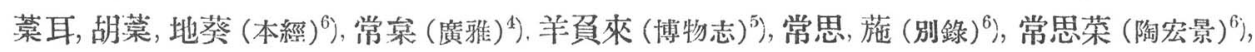

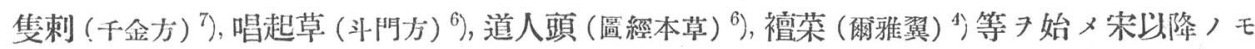
ノチモ加フレバ甚ダ多數二上レリ。而シテ之ガ樂用二關スル記載八神農本草經中品 ${ }^{6}$ )二見

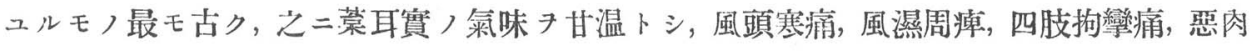

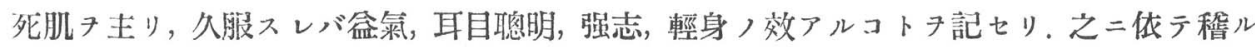
二往昔八專亏其子實于藥用トセシガ如ク, 別錄 $\left.{ }^{6}\right)$ 二テ初メ其葉二關シ《葉味苦辛微寒有小 毒》ト記セルモ，如何ナル治療二用ヒシャ瞭カナラズ, 且ッ陶宏景 ${ }^{6}$ )が《此是常思荣, 傖人 皆食之》又八《方用亦覞稀》等卜記七ル點ヨリ考フル二, 其嫩葉八往時ヨリ鄙民間ノ食用 二供サレシモ, 其藥用二至リテ八葉䁈共二稀用二屬七シモ>、如ク思考サル。然ル二唐以

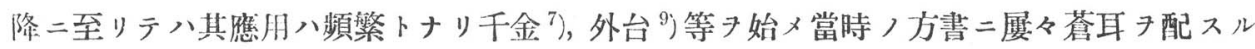

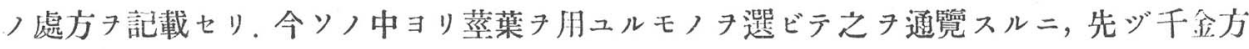
ニ八, 諸風濕丹治シ, 病丹避少, 胃, 脹滿丹去リ, 三蟲丹殺シ, 進食ノ效アルモノトシテ,

治諸風, 當以五月五日午時, 乾地刈取菜耳葉, 洗曝燥淿下篩, 酒若漿水服方寸七, 日三, 作 散若吐逆, 可䍃和䉆丸, 服十元準計一方了七數也, 風輕易治者日再服. 若身體有風處皆作 醀肌出 或如磨豆粒, 此雼風毒出也, 可以針刺潰去之, 㫮黄汁出畫乃此, 五月五日多取除 漧, 著大﨎中稍取用之, 此草辟惡, 若欲看病省疾者便服之, 合人無所畏, 若時氣不和, 舉家 腿之, 若病胃脹滿心悶發熱即服之, 手殺三蛮, 腸痔能進食, 一邈年服之佳, 七月七日, 九月 九日可探用.

卜記シ, 翼方 ${ }^{8}$ )二八, 手足, 崡痛, 牙痛, 一切丁腫, 特疾等キ治スモノトシテ, 夫々

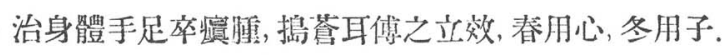

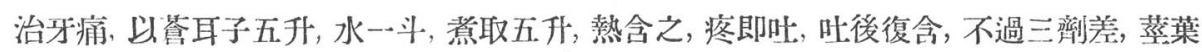
亦得.

治一切丁痛. 取蒼耳根蓝和葉, 燒作灰, 以醋泔澱和如泥, 塗上, 乾即易, 不過十餘度, 即找 出其根。

治五庤方, 荅耳蔡葉, 以五月五日探, 乾篇末, 以水服方寸七, 立效.

トアリ, 又外台秘要 ${ }^{9}$ ) ニモ手足腫痛フ治スルモノトシテ，

療熱毒病攻手足腫疼痛欲脫方, 取荟耳汁以漬之 トアリ, 又齿痛キ治スル方トシテ，

療齒風動痛, 蒼耳一握, 以漿水孚. 入盐含.

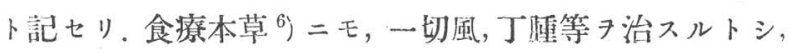

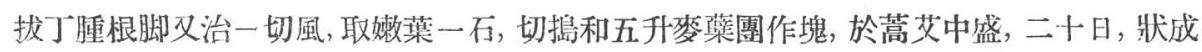

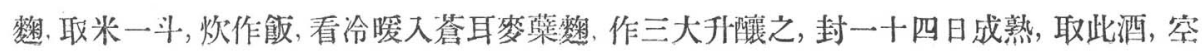


心嗳服之、神驗, 封此酒可兩重布不得全密, 密則溢出, 又不可和馬肉食.

ナル酒方キ揭ら゙, 聖惠方 $\left.{ }^{6}\right)$ 二八婦人, 發疹, 產後下峲二對シ效アリトシテ,

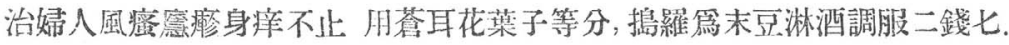

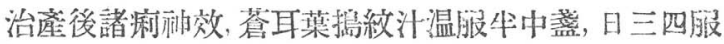

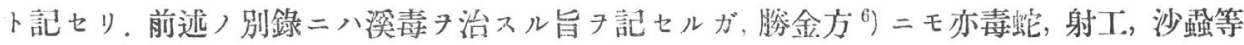
ノ毒傷キ治スル方トシテ,

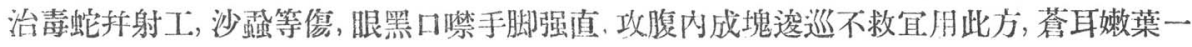

握研取汁, 温酒和灌之, 將㵏厚璂所傷處.

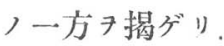

右, 如夕, 唐宋時代二於テ八主トシテ, 風濕, 丁腫, 手足腫痛, 齒痛, 深毒等, 諸症二用七 ラレタルモ, 多クハ單用ニシテ, 而カモソ, 琱法八散劑, 丸劑, 湯劑等トシテ內服スル外, 或

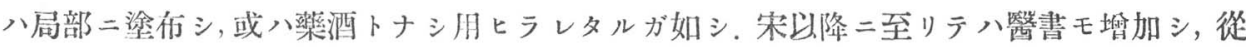

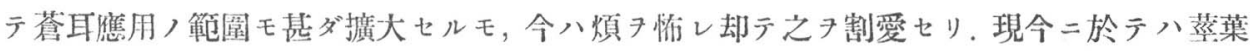
ヨ用フルコトハ稀ナルモ, 子賽八藥舖常眝藥つ一二屬シ, 臨床上屡々應用セラル。

次二六朝時代二其嫩葉ガ食用二供サレシハ前述, 如クナルガ, 千金方 7 ) 食治, 孟詵 , 食療本草 ${ }^{6}$, 残殷, 食醫心鏡 ${ }^{6}$ 等, 膌二之子載七, 更二明. 周憲王, 救荒本草 ${ }^{10}$ ) $=$,

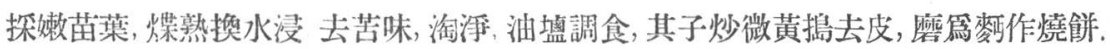
卜葉實共二食用二供シ得ルコトタ示セル二依テ考フルニ, 或地方ニ於テハ古來依然トシテ 食用二供セラレッ、アルコト推定二䧼カラザルナリ。

\section{II. 蒼耳经葉ノ水製越幾斯ノ作用}

\section{A. 實驗材料及ビ其方法}

余八實驗ノ結果酒精浸出液ヨりモ水浸出液二於テ强力ナル作用 7 認メタルガ故二, 先ヅ水溶性成分 二就テ實驗 遂行セリ. 可檢越幾斯ノ製法八次ノ如シ.

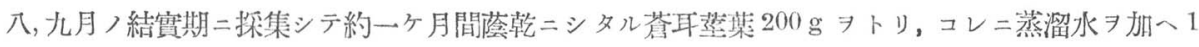

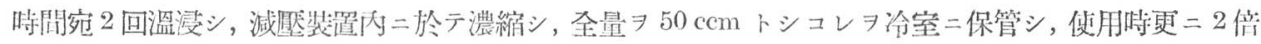
二濃縮, 即チ 8 倍二濃縮七ルモ, 7 原液卜七り。此原液八腐败习怖レ隔日二新二調製七り。少原液中二含

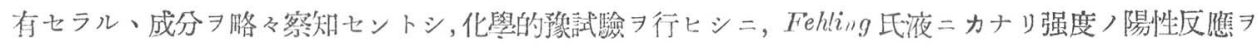
示七几外, Alkaloid, 苦味質等, 区隼八陰性ナリキ.

\section{B. 實 驗 成 績 \\ 1. 一 般 作 用}

\section{a. 金線蛙ニ對スル畵性並ニー般作用}

蛙ニテハ股部淋巴囊内二注射七リ。最小致死量ハ體重 $1 \mathrm{~g}$ ニッキ大約 $23,1 \mathrm{mg}$ 前後ニシテ, 13,1 一 
$17,8 \mathrm{mg}$ 二テ八稍々呼吸緩慢トナリ, 策止狀 7 續クルノミニシテ著變ナキモ， $15,7-23,1 \mathrm{mg}$ 二至レバ自

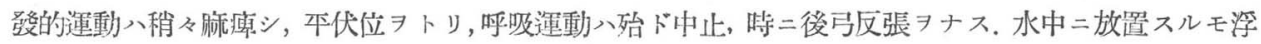
キタルマ、ナリ。中毒症狀基シキモノ八全身麻瘦シ, 反射入全々消失シ，假死ノ㓠態卜ナリ，20洔間稌

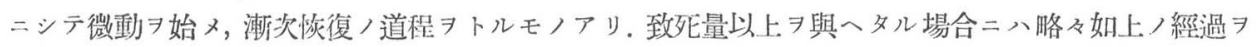

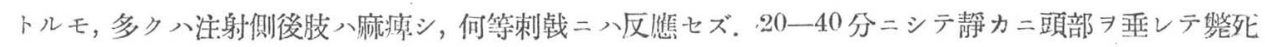
ス (第 1 表參照).

第 1 表. 食線蛙二對 $ス$ 毒性並二一般作用.

\begin{tabular}{|c|c|c|c|c|c|c|}
\hline $\begin{array}{l}\text { 動 物 } \\
\text { 番 號 }\end{array}$ & 體 $(\mathrm{g})$ 重 & $\begin{array}{c}\text { 濃 }(\%) \text { 度 } \\
(\%)\end{array}$ & $\begin{array}{l}\text { 用 量 } \\
\text { (ccm) }\end{array}$ & $\begin{array}{l}\text { 對體重 } \\
\text { (得g) }\end{array}$ & 轉歸 & 一 般 症 \\
\hline 1 & 32,7 & $\begin{array}{l}\text { 原液， } \\
2 \text { 倍 濃 }\end{array}$ & 1,0 & 0,0306 & 死 & 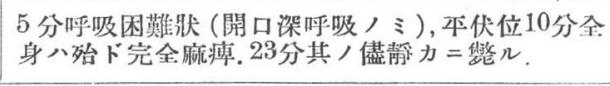 \\
\hline 2 & 29,5 & $"$ & 0,9 & 0,0305 & 死 & 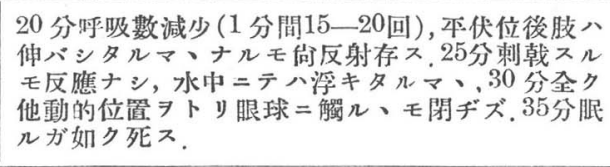 \\
\hline 3 & 33,0 & $"$ & 1,0 & 0,0303 & 死 & 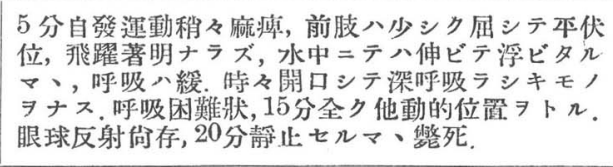 \\
\hline 4 & 31,4 & $"$ & 0,9 & 0,0286 & 死 & 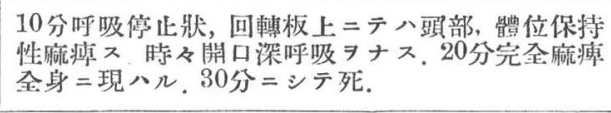 \\
\hline 5 & 31,8 & $"$ & 0,9 & 0,0283 & 死 & 殆ド同上ノ經過ヨトリテ後綮几。 \\
\hline 6 & 29,5 & $"$ & 0,8 & 0,0269 & 死 & 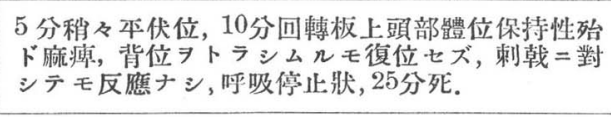 \\
\hline 7 & 32,6 & $"$ & 0,8 & 0,0245 & 死 & 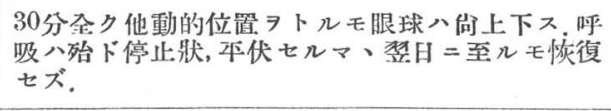 \\
\hline 8 & 33,9 & $"$ & 0,8 & 0,0236 & 死 & 殆ド同上ノ經過ヨトリ 37 分ニシテ綮ル。 \\
\hline 9 & 29,7 & $"$ & 0,7 & 0,0235 & 生 & 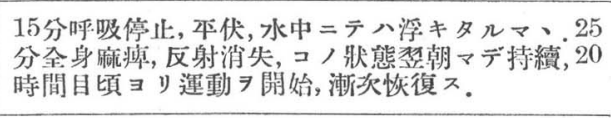 \\
\hline 10 & 34,5 & " & 0,8 & 0,0231 & 死 & 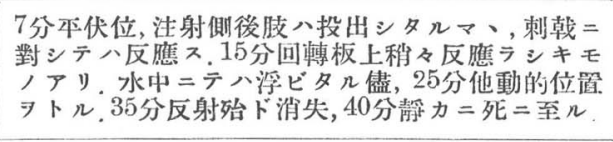 \\
\hline 11 & 30,3 & $"$ & 0,7 & 0,0231 & 死 & 略々同上, 43 分全身麻疩 / 儘, 柆朝平伏位 $=$ テ死. \\
\hline 12 & 31,5 & $"$ & 0,7 & 0,0222 & 生 & 略々同上ナルモ歪日生. \\
\hline 13 & 36,1 & $n$ & 0,8 & 0,0221 & 生 & 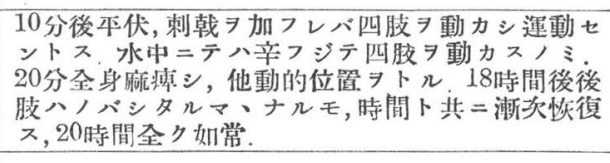 \\
\hline 14 & 34,2 & $”$ & 0,7 & 0,0204 & 生 & 同 上. \\
\hline
\end{tabular}




\begin{tabular}{|c|c|c|c|c|c|c|}
\hline $\begin{array}{l}\text { 勳物 } \\
\text { 番號 }\end{array}$ & $\begin{array}{l}\text { 體 }(\mathrm{g}) \text { 重 } \\
\text { (g) }\end{array}$ & 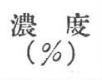 & $\begin{array}{l}\text { 用 量 } \\
(\mathrm{ccm})\end{array}$ & $\begin{array}{l}\text { 對體重 } \\
\text { (海: }\end{array}$ & 轉歸 & - \\
\hline 15 & 34,5 & $\begin{array}{l}\text { 原液 } \\
2 \text { 倍濃 }\end{array}$ & 0,7 & 0,02028 & 生 & 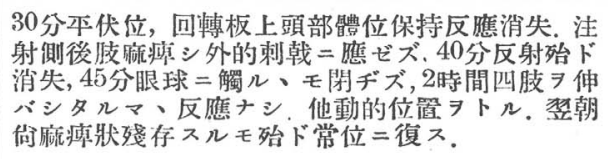 \\
\hline 16 & 33,7 & " & 0,6 & 0,0178 & 生 & 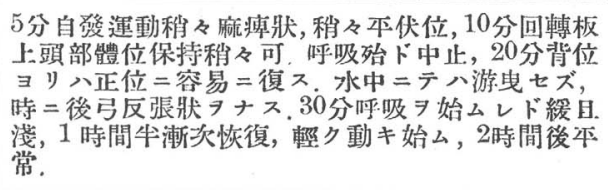 \\
\hline 17 & 33,9 & $"$ & 0,6 & 0,0176 & 生 & 略々同上, 1時間牛後殆ド恢復. \\
\hline 18 & 31,8 & $"$ & 0,5 & 0,0157 & 生 & 同上. \\
\hline 19 & 30,4 & $"$ & 0,4 & 0,0131 & 生 & 10分呼吸緩,其他著變ナシ。 \\
\hline 20 & 29,0 & $"$ & 0,3 & 0,0103 & 生 & 略々同上. \\
\hline 21 & 31,7 & $"$ & 0,1 & 0,0031 & 生 & 著變ナシ。 \\
\hline
\end{tabular}

\section{b. ニ十日鼠二對スル毒性並ニー般作用}

背部皮下: 二原液 ヨ二倍二濃縮セルモ, 7 注射セリ。體重 $1 \mathrm{~g}$ 二對スル最小致死量八 $7,3 \mathrm{mg}$ 內外二

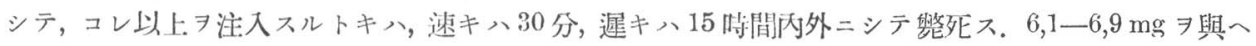

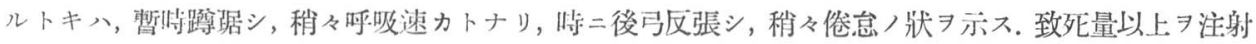

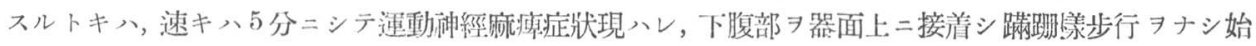

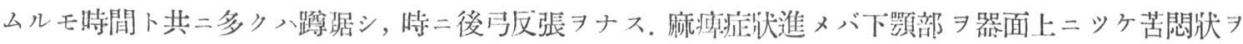

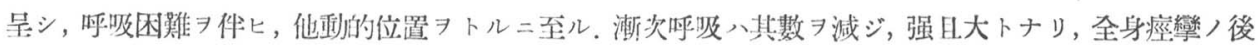
二整レルモノアリ. 而シテュ, 全身症彎入 $9,8 \mathrm{mg}$ 以上ノモノ二認メラル所ニシテ, 注射量ソレ以下二於

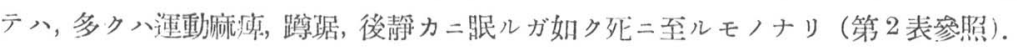

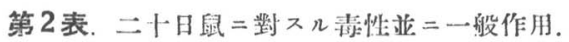

\begin{tabular}{|c|c|c|c|c|c|c|}
\hline $\begin{array}{l}\text { 動物 } \\
\text { 番 號 }\end{array}$ & $\begin{array}{l}\text { 體 } \\
(\mathrm{g})\end{array}$ & $\begin{array}{l}\text { 湮 } \\
(\%) \text { 鹿 }\end{array}$ & $\begin{array}{l}\text { 用 量 } \\
(\mathrm{ccm})\end{array}$ & $\begin{array}{l}\text { 對體重 } \\
(\text { 篟: } \mathrm{g})\end{array}$ & 轉歸 & 一 般 症 狀 \\
\hline 1 & 12,5 & $\begin{array}{l}\text { 原液, } \\
2 \text { 倍濃 }\end{array}$ & 0,5 & 0,04 & 死 & 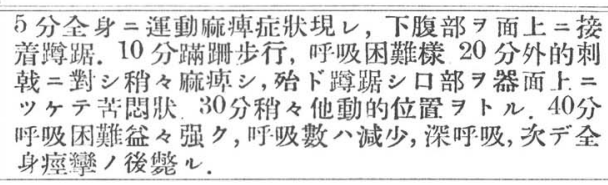 \\
\hline 2 & 10,5 & $"$ & 0,4 & 0,038 & 死 & 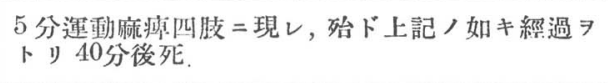 \\
\hline 3 & 10,0 & $"$ & 0,3 & 0,030 & 死 & 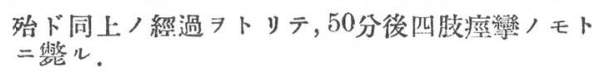 \\
\hline 4 & 9,5 & $"$ & 0,2 & 0,021 & 死 & 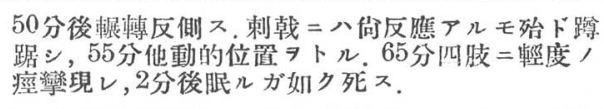 \\
\hline
\end{tabular}




\begin{tabular}{|c|c|c|c|c|c|c|}
\hline $\begin{array}{l}\text { 動物 } \\
\text { 番 號 }\end{array}$ & $\begin{array}{l}\text { 體 } \\
(g)\end{array}$ & $\begin{array}{c}\text { 濃 }(\%) \\
(\%)\end{array}$ & $\begin{array}{l}\text { 用 量 } \\
(\mathrm{ccm})\end{array}$ & $\begin{array}{l}\text { 對體重 } \\
\text { (海g) }\end{array}$ & 轉歸 & 一 般 症 唹 \\
\hline 5 & 10,2 & $\begin{array}{l}\text { 原液 } \\
2 \text { 倍裴 }\end{array}$ & 0,1 & 0,0098 & 死 & 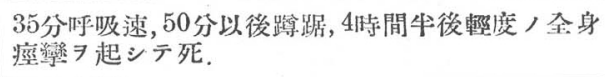 \\
\hline 6 & 10,5 & $"$ & 0,1 & 0,0095 & 死 & 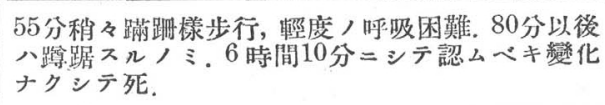 \\
\hline 7 & 11,3 & $"$ & 0,1 & 0,00885 & 死 & 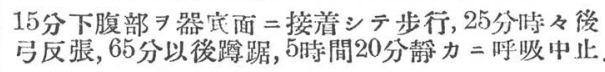 \\
\hline 8 & 12,8 & $"$ & 0,1 & 0,0078 & 死 & $\begin{array}{l}\text { 略々同上. } 7 \text { 時間半開ロシテ呼吸シ全身㾏攣/ } E \\
\text { ト }\end{array}$ \\
\hline 9 & 10,1 & $20 \%$ & 0,4 & 0,0078 & 死 & 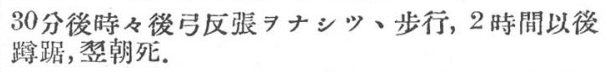 \\
\hline 10 & 11,8 & $"$ & 0,45 & 0,0076 & 死 & 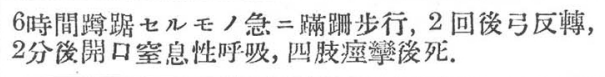 \\
\hline 11 & 11,8 & $"$ & 0,45 & 0,0076 & 死 & 8時間靜カ \\
\hline 12 & 12,0 & $"$ & 0,45 & 0,0075 & 死 & 15分後弓反張, 呵吸秘子速, 30 分後嗱踞柆朝死. \\
\hline 13 & 12,3 & " & 0,45 & 0,0073 & 死 & 2時開後嗱踞セルマ、8時間ニシテ死。 \\
\hline 14 & 11,4 & $"$ & 0,4 & 0,0070 & 生 & 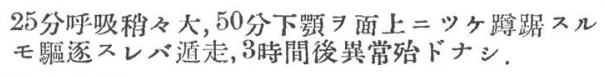 \\
\hline 15 & 11,5 & " & 0,4 & 0,0069 & 生 & 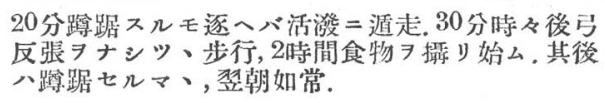 \\
\hline 16 & 13,2 & $"$ & 0,45 & 0,0068 & 止 & 蹲踞セ儿儘, 歪朝台生。 \\
\hline 17 & 12,6 & " & 0,4 & 0,0063 & 生 & $\begin{array}{l}\text { 今マデ䠗踞ヤ、呼吸促迫感アリシモノガ2時間後 } \\
\text { 八食物 }\end{array}$ \\
\hline 18 & 9,5 & " & 0,3 & 0,0063 & 生 & 稍々呼吸困難樣ナルモ30分後八如常. \\
\hline 19 & 11,4 & .. & 0,35 & 0,0061 & 生 & $\begin{array}{l}\text { 10分1回後弓反張栐動作, 呼吸稍々速, 其後八漱次 } \\
\text { 舊=復ス. }\end{array}$ \\
\hline 20 & 10,3 & $"$ & 0,25 & 0,0048 & 生 & 著變ナシ。 \\
\hline
\end{tabular}

\section{c. 家鬼ニ對スル淎性並ニ一般作用}

體重 $1,16-1,47 \mathrm{~kg}$ /家鬼二, 耳静脈ヨリ1,0-2,0 c cm / 原液 $\exists$ 注射スルモ,一般症狀二八著シキ變 化习認メズ.

\section{2. 摘出家鬼腸管二及ボス作用}

實驗八Magnuৎ氏法二基キ，腸管二種々涱度，可檢液习與へテ其作用习檢セリ。

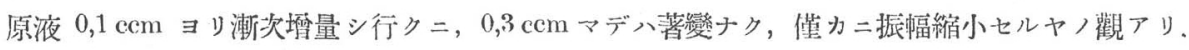

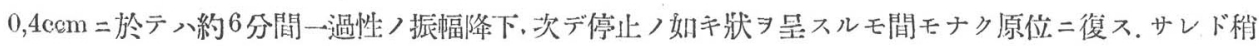

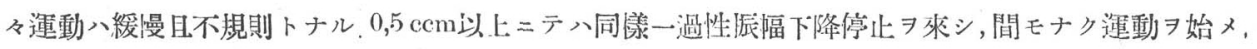


振幅ハ漸進的二增大スルモ, 其大サ八舊二復シ得ズ. $1,5 \mathrm{ccm}$ 以上入恢復力減弱シ, 運動ハ續行スルモ數

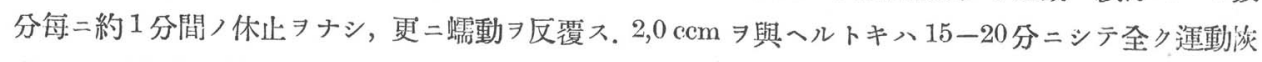

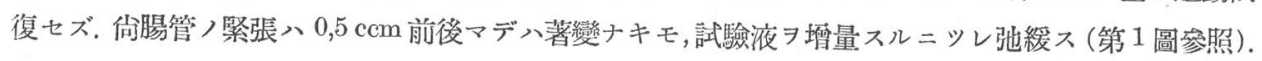

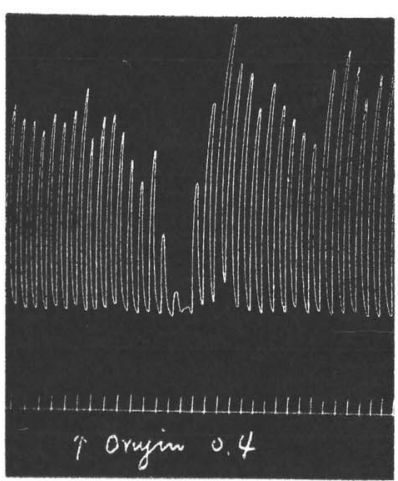

A

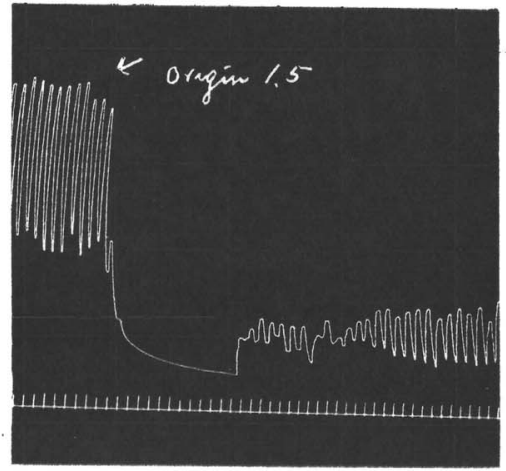

B

第 1 圖. 摘出家鬼腸管=及ポス作用.

\section{3. 摘出蟇心臟 對スル作用}

八木上法二基キテ處置セル䓪摘出心臟ニ就キテ行へル實驗ニヨレバ, 原液 $0,05-0,15 \mathrm{~cm}$ ヨ與フル トキハ, 始メ八稍々一過性二興舊シ振幅大トナリ, 次デ振幅ヤ、小サク,些少ナガラ心搏動抑制サレルカ 人如キ狀態习示ス. 原液 $0,175 \mathrm{ccm}$ 以上八急激二心室八收縮停止スル 看ルモ, 心房八不完全ナガラ拱 張收縮運動 續ケ, $0,5 \mathrm{ccm}$ 二於テモ侗靜止ニ至ラズ.

即于第 2 圖二於テ見ル如ク, 蒼耳越幾斯) 少量八强心性二, 其過量八抑制的二作用スルラ認ム (第 2 圖參照).

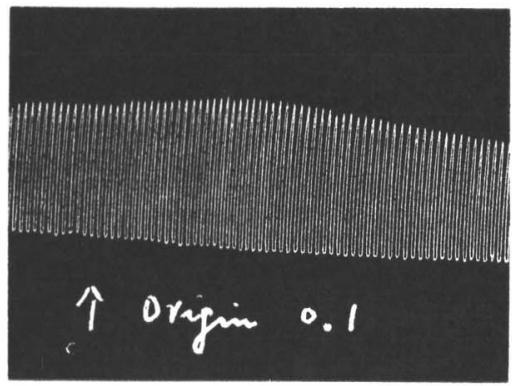

A

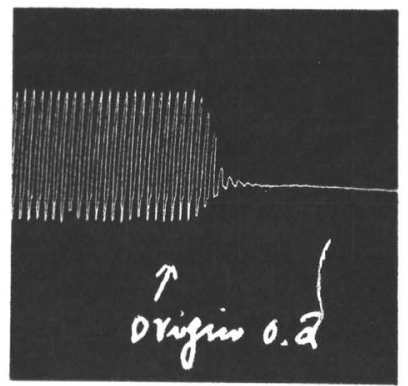

B

第 2 圖. 摘出幕心臟 =及ボス作用.

\section{4. 呼吸及ビ盈竰二及ボス作用}

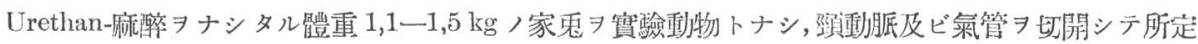
, 装置 7 施シ,一定時 7 經テ, 血㰮呼吸曲線, 恒性 7 得 几影㗽习觀察七リ。

體重 $1 \mathrm{~kg}=$ 對シ試驗夜 $0,19 \mathrm{ccm}$ ヨ注入スルニ, 殆ド變化习認メ得ザルモノアリ, 或ハ直後 $10-15$ 


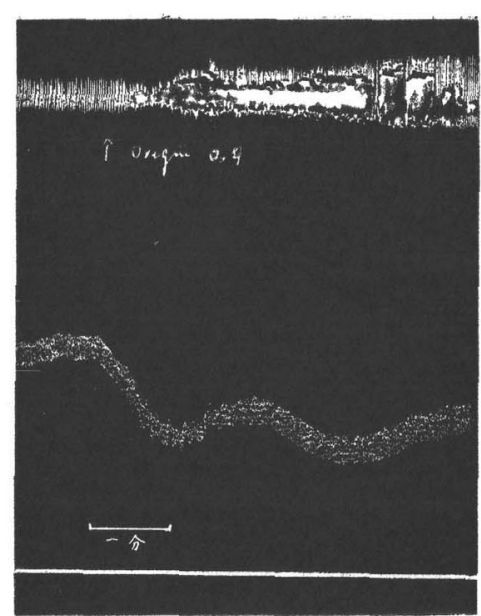

第3 圖. 家兔呼吸及ビ血緊二 及ボス作用。
秒間呼吸頻數, 振幅 ハ一洔的ニ小トナリ, 後却ッテ以前ヨリ 振幅大トナルモノアリ。サレド其作用ハー滑性ナリ。血壓モ

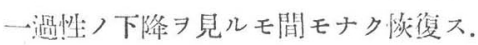

$1 \mathrm{~kg}$ ニツキ $0,3 \mathrm{ccm}$ 以上 $\exists$ 注射スルトキハ, カナリ著罒 ナル變化习來タシ, 呼吸入一時停止スルモノアリ又八振幅小 トナルモノアリ、數秒後八上記ノ如ク振幅却ッテ大トナリ頻

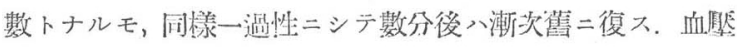
モ同壯二降下シ，呼吸二變化アル間影響习蒙儿如シ。

憾ムラクハ, 圾驗液つ水溶性ナルタメ鼠败シ易多, 其綡 化スルヨ恐レテ，2日每ニコレヨ作リシコト, 及ビ蒐集セル 試粼二同一修件ヨ得ザリシタメ, 試液, 恒定习得ズ, 㓜論動 物，體質ニヨリテモ左右サル、所多ク，其作用ニカナリノ强 弱ヨ認メタリ(第3 圖參照).

\section{5. 真管二及ボス作用}

實噞、Ti endelenburg氏法二基キ墓, 後肢灌流习行へリ.

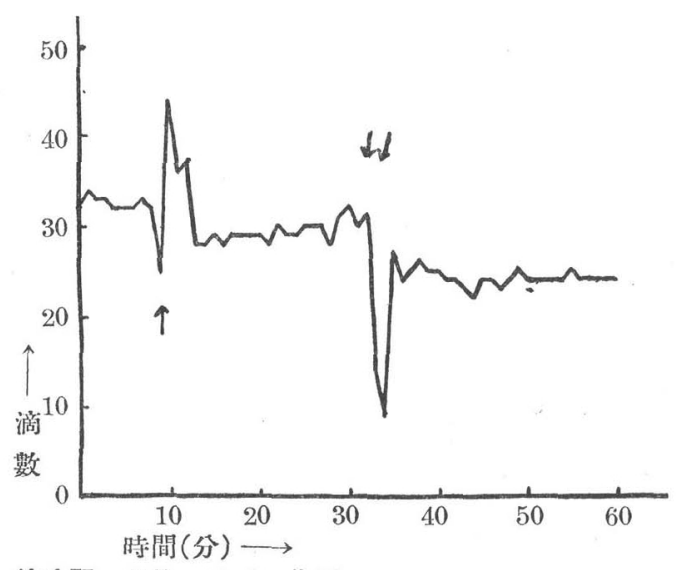

第 4 圖. 血管二及ボス作用.

$\uparrow: 20 \%$ 溶液 $1,0 \mathrm{ccm}$ 注入,

个：原液 $0,2 \mathrm{ccm}$ 注入.
滴數 一一定スル 待チテ, 稀䅸試驗液 接續ごも留

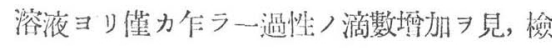

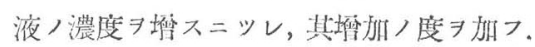
然ル $=0,1 \mathrm{~cm}$, 原液 $\ni$ 注、スルカ, $0,4 \%$, 稀釋液 コこさ管二注入スルトキハ, 却ッテ榈 數ノ減少ヨ來タス. 而シテュノ減少モ一過性 ニシテ, 5-10分)後漸次恢復)牀 $习$ 示ス(第 4 圖參照).

總

以上本篇二於テ述べタル處子總括スレバ次ノ如シ。

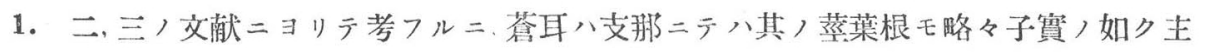
二風濕.丁腫, 金痛, 解毒藥, 皮膚病藥トシテ朋七ラレタルガ如シ.

2. 蒼耳越幾斯, 一般中毒症狀八蛙及ビ二十日鼠二テハ筋運動, 進行性麻聼ニシテ, 
家鬼二於テハ殆ド影響キ見ラレズ.

3. 摘出家兔腸管二對シテハ抑制的二作用ス. 中等量以上ハ運動緩慢トナリ一過性二 停止スルモ, 數分後又僅カニ運動ヲ始ム。

4. 心臟二對シテハ, 少量二於テ八稍々興奮性二作用スルモ, 中等量以上ハ却ツテ運 動ハ障淂サレ, 心室ノ收縮ハ止ルモ，心房ハ僅カナガラ不規則二擴張收縮運動フ續ク。

5. 呼吸ハ蒼耳越幾斯ノ注入ニヨリテ障碍サレ, 時ニ一過性ノ停止 來ス.

血壓モ嘅ネ一過性ノ下降キ來ス,

6. 㱳後肢血管ハ少量ニョリ一過性二擴張シ, 多量ハ却ッテ收縮サル。

叙上ノ所見ニヨリ荅耳, 䓠葉中二或種, 神經筋肉毒, 含有七ラル、八推知二難カラザ ル處ナルモ, 其水浸液, 作用ノ概シテ微弱ナルハ, 有效成分自己, 性狀ニヨルカ, 或八其含 有量ノ稀少ナルニ基ケルカ, 更二實驗フ加フルニ非ザレバ斷ジ難シ.

擱筆ニ臨ミ恩師久保田敉授ノ御校閱 7 謝 ス.

\section{引用書 目}

1) Dragendorff, G.: Die Heilpflanzen der verschiedenen Völker und Zeiten 669 (1898).

2) Zander: Pharm. z. Russland 661, 20 (1881). Zit. n. Wehmer, C., Die Pflanzenstoffe 2, 1223 (1931).

3) 毛詩名物圖說：淸, 徐焋撰.

4) 爾雅義疏: 清, 郝㰻行捛.

5) 太本御覽：策, 李助等撰.

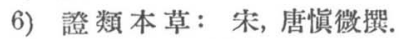

7) 千金方：唐, 孫思邀搇.

8) 千金翼方: 同上.

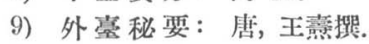

10) 救茫本草: 明, 周憲王撰. 